\title{
PKC-dependent phosphorylation of Munc18a at Ser313 in activated RBL-2H3 cells
}

\author{
Pratikshya Adhikari and Hao Xu* \\ Department of Biological Sciences, University of Southern Mississippi, 118 College Drive, \#5018, \\ Hattiesburg, MS 39406
}

\begin{abstract}
Protein Kinase C (PKC) regulates the release of pro-inflammatory compounds from IgE/antigenactivated mast cells by unknown mechanisms. In this study, we show for the first time that PKC inhibitor Ro-03-0432, which inhibits RBL-2H3 exocytosis/degranulation in a concentration dependent fashion, prevents the phosphorylation of membrane fusion factor Munc18a at Ser 313. Our study provides fresh evidence that PKC-dependent protein phosphorylation may contribute to the intricate regulation of mast cell degranulation by directly targeting the fusion factors.
\end{abstract}

\section{Introduction}

In mammalian cells, SNARE-dependent exocytosis is coordinated by any of the three Munc18 isoforms ( $a, b$, and c). Recently, Munc18a was found sufficient for FceRI-mediated release of $\beta$-hexosaminidase from activated RBL-2H3 cells (a tumor analog of mucosal mast cells) [1]. Surprisingly, recombinant Munc18a was incapable of promoting exocytic fusion mediated by VAMP8/syntaxin4/SNAP23 [2], three SNAREs that underlie $\beta$-hexosaminidase release [3]. This has raised the possibility that signaling-dependent phosphorylation might be required to activate the fusion machinery.

In neurotransmission and chromaffin cell exocytosis, PKC-dependent phosphorylation of Munc18a reduces its affinity for syntaxin 1 and changes the kinetics of transmitter release [4; 5]. In vitro, PKC directly targets Munc18a at Ser306 and Ser313 [6], both of which are located on domain 3a of Munc18a, which undergoes conformational change [7] to promote trans-SNARE zippering [8]. In this study, we investigated PKC-dependent phosphorylation of Munc18 at S313 in IgE/antigen-activated RBL-2H3.

\section{Materials and Methods}

\section{Antibodies}

Affinity-purified antibodies specific for Ser313 phosphorylated Munc18a (sc-28459-R; Santa Cruz) was raised against a short amino acid sequence containing phosphorylated Ser313 of hMunc18a (sc-28459-P; Santa Cruz). Anti-Actin (sc-1616, Santa Cruz) was raised against a peptide mapping at the $\mathrm{C}$-terminus of human actin.

\footnotetext{
*Corresponding author: hao.xu@usm.edu.
} 


\section{Mast cell secretion assay}

RBL-2H3 cells (ATCC) were maintained and activated according to published protocols [9]. Where indicated, Ro-03-0432 (Santa Cruz) or DMSO was added 30 min prior to the addition of antigen or ionomycin. $\beta$-hexosaminidase activity was assayed as previously described [9]. $\beta$-hexosaminidase secretion was expressed as a percentage of the activity in the medium relative to the total activity. To determine if Ro-03-0432 exerts any direct effect on the enzymatic activity of $\beta$-hexosaminidase, RBL-2H3 cells were activated by $1 \mu \mathrm{M}$ of ionomycin and $30 \mu \mathrm{L}$ of the supernatant were mixed with Ro-03-0432 at specified concentrations and used for $\beta$-hexosaminidase activity measurement as described above.

\section{Phosphoprotein isolation and detection}

RBL-2H3 cells in three T-25 flasks were grown to $85 \%$ confluency. Two flasks received 2.5 $\mathrm{mL}$ of fresh complete medium containing $0.5 \mu \mathrm{g} / \mathrm{mL}$ of anti-TNP IgE but the $3^{\text {rd }}$ flask received just fresh complete medium. Following $2 \mathrm{hr}$ incubation, Ro-03-0432 $(20 \mu \mathrm{M})$ was added to IgE-sensitized cells while the non-sensitized cells received DMSO. After $30 \mathrm{~min}$ of further incubation, each flask was washed twice with $2.5 \mathrm{~mL}$ of RPMI 1640 and then incubated with $2.5 \mathrm{~mL}$ of RPMI 1640 containing $1 \%$ BSA and $50 \mathrm{ng} / \mathrm{mL}$ of TNP-BSA for $20 \mathrm{~min}$. After medium removal, the flasks were washed three times with $7 \mathrm{~mL}$ of $5 \mathrm{mM}$ HEPES-Na, pH7.4, $150 \mathrm{mM} \mathrm{NaCl}$. Phosphoproteins were then isolated using a Qiagen phosphoProtein Purification Kit by following the manufacturer's instructions.

\section{Results and Discussion}

To investigate PKC-dependent modification of the degranulation machinery, we exploited selective, cell-permeable PKC inhibitor Ro-32-0432 [10] in a cell-based secretion assay. At $5 \mu \mathrm{M}$, Ro-32-0432 inhibited over $65 \%$ of $\beta$-hexosaminidase secretion from RBL-2H3 cells, and at $20 \mu \mathrm{M}$, about $95 \%$ (Fig. 1A). Meanwhile, Ro-32-0432 does not interfere with either $\beta$-hexosaminidase activity or the enzymatic assay at the concentrations we used (hatched column).

To assess if Munc18a could be the target of PKC in mast cell degranulation, we extracted proteins from resting and activated RBL-2H3 cells, including cells activated in the presence of Ro-32-0432. Phosphorylated and non-phosphorylated proteins were separated into two fractions (Eulate and FT), and subject to SDS-PAGE and immunoblotting. While actins exist in unphosphorylated states regardless of the treatment, phosphorylated Munc18a at Ser313 was detected exclusively in activated RBL-2H3 cells (Fig. 1B), using anti-phosphoMunc18a (pSer313) raised against a phosphopeptide derived from Munc18a. The phosphoMunc18a band disappeared (middle panel), as expected, when the antibody was preincubated with the phosphopeptide. Importantly, this phosphorylated Munc18a was not observed in RBL cells activated in the presence of Ro-32-0432, demonstrating that Munc18a phosphorylation at Ser313 in RBL cells is PKC dependent. These findings suggest that PKC-dependent phosphorylation of Munc18a at S313 could be the missing link between signaling and degranulation. We expect future investigations of the biochemical and physiological consequences of Munc18a phosphorylation to generate exciting new insights on the regulation of allergic inflammatory. 


\section{References}

1. Bin NR, Jung CH, Piggott C, Sugita S. Crucial role of the hydrophobic pocket region of Munc18 protein in mast cell degranulation. Proc Natl Acad Sci U S A. 2013; 110:4610-5. [PubMed: 23487749]

2. Xu H, Arnold MG, Kumar SV. Differential Effects of Munc18s on Multiple Degranulation-Relevant Trans-SNARE Complexes. PLoS One. 2015; 10:e0138683. [PubMed: 26384026]

3. Lorentz A, Baumann A, Vitte J, Blank U. The SNARE Machinery in Mast Cell Secretion. Front Immunol. 2012; 3:143. [PubMed: 22679448]

4. Barclay JW, Craig TJ, Fisher RJ, Ciufo LF, Evans GJ, Morgan A, Burgoyne RD. Phosphorylation of Munc18 by protein kinase C regulates the kinetics of exocytosis. J Biol Chem. 2003; 278:10538-45. [PubMed: 12519779]

5. Genc O, Kochubey O, Toonen RF, Verhage M, Schneggenburger R. Munc18-1 is a dynamically regulated PKC target during short-term enhancement of transmitter release. Elife. 2014; 3:e01715. [PubMed: 24520164]

6. Fujita Y, Sasaki T, Fukui K, Kotani H, Kimura T, Hata Y, Sudhof TC, Scheller RH, Takai Y. Phosphorylation of Munc-18/n-Sec1/rbSec1 by protein kinase C: its implication in regulating the interaction of Munc-18/n-Sec1/rbSec1 with syntaxin. J Biol Chem. 1996; 271:7265-8. [PubMed: 8631738]

7. Hu SH, Christie MP, Saez NJ, Latham CF, Jarrott R, Lua LH, Collins BM, Martin JL. Possible roles for Munc18-1 domain 3a and Syntaxin1 N-peptide and C-terminal anchor in SNARE complex formation. Proc Natl Acad Sci U S A. 2011; 108:1040-5. [PubMed: 21193638]

8. Parisotto D, Pfau M, Scheutzow A, Wild K, Mayer MP, Malsam J, Sinning I, Sollner TH. An extended helical conformation in domain 3a of Munc18-1 provides a template for SNARE (soluble $\mathrm{N}$-ethylmaleimide-sensitive factor attachment protein receptor) complex assembly. J Biol Chem. 2014; 289:9639-50. [PubMed: 24532794]

9. Suzuki K, Verma IM. Phosphorylation of SNAP-23 by IkappaB kinase 2 regulates mast cell degranulation. Cell. 2008; 134:485-95. [PubMed: 18692471]

10. Birchall AM, Bishop J, Bradshaw D, Cline A, Coffey J, Elliott LH, Gibson VM, Greenham A, Hallam TJ, Harris W, et al. Ro 32-0432, a selective and orally active inhibitor of protein kinase C prevents T-cell activation. J Pharmacol Exp Ther. 1994; 268:922-9. [PubMed: 8114006] 

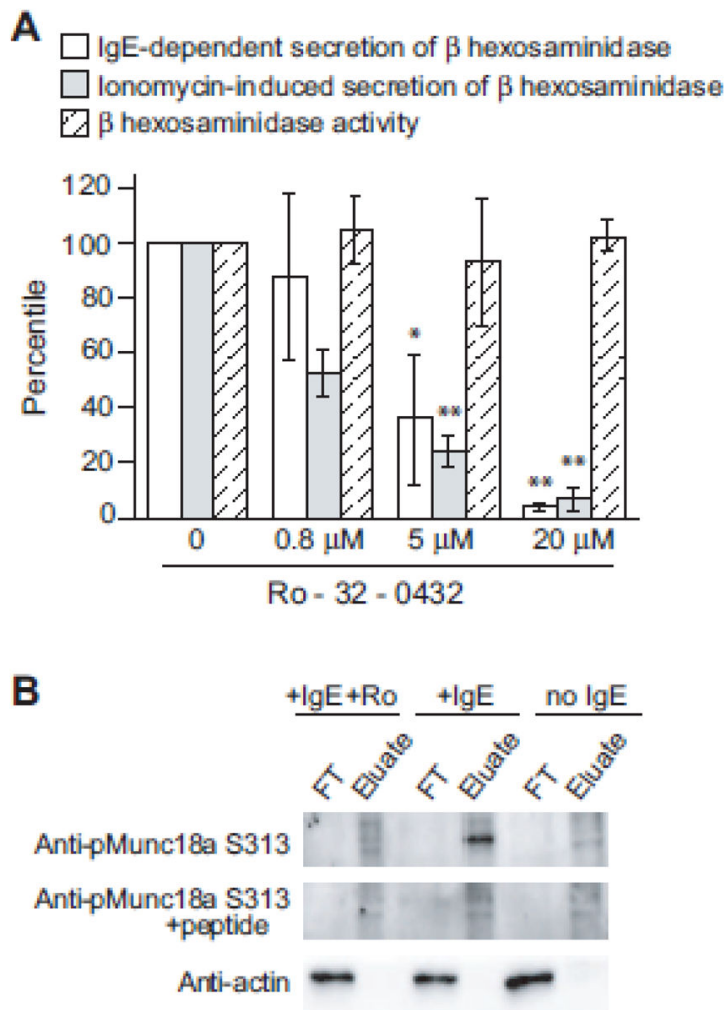

Figure 1. PKC inhibitor prevents mast cell degranulation and Munc18a phosphorylation at Ser313

A) RBL-2H3 cells treated with Ro-32-0432 or DMSO were activated with either anti-TNP IgE/TNP-BSA (white columns) or ionomycin (gray columns) and then assayed for $\beta$ hexosaminidase release, which was calculated as described in Materials and Methods. The value of the DMSO-treated sample was set as $100 \%$, and used to determine the relative values of other conditions. Likewise, the effect of Ro-32-0432 on $\beta$-hexosaminidase activity was also measured and the values relative to the DMSO-treated sample were presented (hatched columns). Error bars indicate SD $(n=3)$. Student T test was used for statistical analysis. * means $\mathrm{p}<0.05$; ** means $\mathrm{p}<0.01$. B) RBL-2H3 cells incubated under specified conditions were lysed by CHAPS, with phosphorylated proteins and non-phosphorylated proteins separated into the FT (Flow-through) and the Eluate fractions. Two $\mu$ g of total protein from each fraction were used subsequently in SDS-PAGE and western blotting. The data is representative of 3 independent experiments. 